\title{
NILAI SOSIAL DALAM NOVEL “AYAH” KARYA ANDREA HIRATA: KAJIAN SOSIOLOGI SASTRA
}

\author{
Mika Rosianti ${ }^{1}$, Mukti Widayanti ${ }^{2}$, Yohanes Sugiyanto ${ }^{3}$ \\ ${ }^{1,2,3}$ Program Studi Pendidikan Bahasa dan Sastra Indonesia \\ Fakultas Keguruan dan Ilmu Pendidikan \\ Universitas Veteran Bangun Nusantara Sukoharjo, Jawa Tengah, Indonesia \\ Author Correspondence: mukti.widayati@yahoo.co.id
}

\begin{abstract}
ABSTRAK
Tujuan penelitian ini adalah mendeskripsikan nilai-nilai sosial dan implementasi nilai sosial dalam novel "Ayah" karya Andrea Hirata sebagai bahan pembelajaran bahasa Indonesia di Sekolah Menengah Atas. Penelitian ini menggunakan pendekatan deskriptif kualitatif. Sumber data penelitian ini adalah novel "Ayah" karya Andrea Hirata yang diterbitkan oleh Bentang Pustaka cetakan keempat tahun 2015 dengan tebal 412 halaman. Prosedur pengumpulan data menggunakan teknik pustaka, teknik baca, dan teknik catat. Prosedur analisis data menggunakan Content Analysis. Hasil penelitian dapat disimpulkan bahwa nilai-nilai sosial yang ada dalam novel "Ayah" karya Andrea Hirata mencakupi: kepedulian sosial antarsesama, antarsahabat, antara guru dan muridnya; hubungan kasih sayang antarsesama, antara kakak dengan adiknya, antara anak dengan ayahnya, anak dengan kedua orang tuanya, suami dan istri, ayah dengan anaknya, dan anak dengan ibunya; sikap kebersamaan meliputi: antarsesama, antarsahabat, dan ayah dan anak; sikap menghormati dan santun meliputi: kepada orang tua, kepada aktivitas kompetisi atau pertandingan; sikap tolong-menolong meliputi: antara orang tua dengan anaknya, antarsesama, dan antarteman; dan sikap toleransi meliputi: antara anak dan ayah dan antarsesama.
\end{abstract}

Kata Kunci: nilai sosial dan sosiologi sastra

\begin{abstract}
S
The purpose of this study is to describe social values and the implementation of social values in the novel "Ayah" by Andrea Hirata as Indonesian language learning material in High Schools. This research use desciptive qualitative approach. The data source of this research is the novel "Ayah" by Andrea Hirata, published by Bentang Pustaka, the fourth printing in 2015 with 412 pages thick. Data collection procedures using library techniques, reading techniques, and note taking techniques. Data analysis procedures using Content Analysis. The results of the study can be concluded that the social values contained in the novel "Ayah" by Andrea Hirata include: social care between friends, between friends, between teacher and student; interpersonal relationships, between brother and sister, between child and father, child with both parents, husband and wife, father and child, and child and mother; the attitude of togetherness includes: between people, friends, and father and son; respect and courtesy including: to parents, to competition or competition activities; a helping attitude includes: between parents and their children, between people, and between friends; and tolerance include: between child and father and between people.
\end{abstract}

Keywords: social values, sociology of literature

\section{PENDAHULUAN}

Sastra salah satu hiburan bagi orang yang suka membaca, selain hiburan sastra juga memberi inspirasi bagi penikmatnya. Sastra diciptakan oleh pengarang melalui pikiran dan gagasan yang dituangkan dalam bentuk tulisan dengan menggunakan bahasa yang indah sebagai mediumnya dan diluapkan dengan segala perasaanya. Pengarang tidak hanya menulis dengan bahasa yang indah, namun di dalam karya sastra pengarang juga menyelipkan nilai-nilai yang terdapat dalam masyarakat. Tjahjono (1988:29) mengungkapkan secara sederhana "sastra adalah 
ungkapan rasa estetis manusia dengan memakai bahasa "indah" sebagai alat ekspresinya." Sebagaimana diungkapkan Endraswara (2013a:14-15) "sastra akan menjadi sesuatu yang menarik dan dibutuhkan oleh masyarakat jika mengandung aspek-aspek yang sekurang-kurangnya ada pada setiap manusia. Apek-aspek termaksud tidak lain adalah interaksi sosial. Dalam interaksi, manusia sering menggunakan simbol tertentu."

Salah satu permasalahan yang sering ada dalam karya sastra adalah nilai sosial. "Nilai sosial sangat penting karena manusia adalah makhluk sosial yang senantiasa berhubungan (berinteraksi) dengan manusia lain dalam suatu kelompok." (Setiadi, Elly, dan Kolip, 2011:5). Dalam hal ini diciptakanlah sebuah karya sastra sebagai media untuk menyampaikan nilai-nilai yang berhubungan dengan keadaan baik buruk suatu perilaku manusia.

Andrea Hirata merupakan penulis Indonesia yang namanya sudah melambung tinggi dengan karyanya yang pertama yaitu novel "Lasakar Pelangi". Sejak saat itu Andrea Hirata aktif dalam menulis novel, dia sudah menulis beberapa novel antara lain: Laskar Pelangi (2005), Sang Pemimpi (2006), Edensor (2007), Maryamah Karpov, Padang Bulan dan Cinta di Dalam Gelas (2010), Sebelas Patriot (2011), Laskar Pelangi Song Book (2012), Ayah (2015).Karya yang terbaru dari Andrea Hirata adalah novel "Ayah" yang menggambarkan hubungan ayah dengan anak dan seorang laki-laki yang sangat mencintai satu perempuan saja.

Berdasarkan latar belakang dan pembatasan masalah di atas, dapatdirumuskan permasalahan yaitu bagaimana nilai-nilai sosial dalam novel "Ayah" karya Andrea Hirata?Sesuai dengan rumusan masalah yang ada, penelitian ini bertujuan untuk mendeskripsikan nilai-nilai sosial dalam novel "Ayah" karya Andrea Hirata.

Novel dalam bahasa Inggris kemudian masuk ke Indonesia, dalam bahasa Itali novella dan dalam bahasa Jerman novella. Secara harfiah novella berarti 'sebuah barang baru yang kecil', dan kemudian diartikan sebagai 'cerita pendek dalam bentuk prosa' Abrams (Nurgiyantoro, 2007:9). Novel salah satu jenis karya sastra fiksi yang di dalamnya memaparkan suatu permasalahan yang diciptakan oleh pengarang supaya bisa dinikmati pembaca. Agar novel itu menarik, pengarang memberikan konfik-konflik antartokohnya selain konflik pengarang juga menggambarkan situasi tertentu yang mempertegas permasalahan yang ada. Penggambaran permasalahan tersebut bertujuan untuk menyampaikan isi atau pesan dari novel kepada pembaca "Novel merupakan karya imajinatif yang mengisahkan sisi utuh atas problematika kehidupan seseorang atau beberapa orang tokoh" (Kosasih, 2012:60).

Novel menawarkan perbagai permasalahan antara manusia dan kemanusiaan, hidup dan kehidupan dari hasil penghayatan pengarang yang dilakukan dengan kesungguhan, kemudian diungkapkan kembali melalui sarana fiksi (bersifat imajinatif, namun biasanya masuk akal dan mengandung kebenaran yang mendramatisasikan hubungan-hubungan antarmanusia) sesuai dengan pandangannya.

Novel merupakan salah satu bentuk karya fiksi yang strukturnya kompleks. Struktur menunjukan pada susunan atau tata urutan unsur-unsur yang saling berhubungan antara bagian yang satu dengan bagian yang lain atau ditentukan oleh adanya unsur-unsur cerita yang satu dengan yang lainnya.

Unsur-unsur yang membangun karya sastra salah satunya novel adalah:

1. Unsur Intrinsik

"Unsur intrinsik merupakan hal-hal yang membangun karya sastra itu dari dalam" (Tjahjono, 1988:44). Nurgiyantoro (2007:23) mengatakan bahwa, "unsur intrinsik adalah unsurunsur yang membangun karya sastra itu sendiri, unsur-unsur yang (secara langsung) turut serta membangun cerita." Stanton (Budiyono, 2013:31), "karya fiksi (novel) dibangun atas tiga unsur, yaitu: fakta cerita, tema, dan sarana sastra. Fakta cerita terdiri atas karakter, alur, dan latar. Sarana sastra meliputi: sudut pandang, gaya, dan tone."Sebagaimana dikemukakan Kosasih (2012: 6071), "struktur novel dibentuk oleh unsur-unsur yaitu: tema, alur, latar, penokohan, point of view atau sudut pandang, amanat, dan gaya bahasa."Adapun unsur-unsur yang terdapat di dalam novel adalah tema, tokoh, alur (plot), latar (setting), sudut pandang, amanat, dan gaya bahasa.

Berdasarkan beberapa pendapat yang sudah dipaparkan di atas dapat disimpulkan bahwa struktur novel khususnya unsur intrinsik yang membangun novel dari dalam meliputi: tema, alur, 
tokoh, latar, amanat, sudut pandang, dan gaya bahasa. Penulis memaparkan pengertian dari unsur intrinsik hanya untuk memahami tidak untuk mengaplikasikan dalam penelitian, karena bukan tujuan akhir dari penelitian ini.

2. Unsur Ekstrinsik

Adapun unsur ekstrinsik yang membangun karya sastra dari luar menyangkut aspek sosiologi, psikologi, religiusitas, dan lain-lain. Karya sastra tidak bisa tumbuh sendiri, tetapi selalui berhubungan secara ekstrinsik dari luar sastra. Jadi, unsur ekstrinsik merupakan unsur yang membentuk karya sastra dari luar sastra itu sendiri dan untuk melakukan pendekatan terhadap unsur ekstrinsik, diperlukan pendekatan sosiologi, psikologi, religiusitas, filsafat, dan lain-lain.

Kosasih (2012:72) berpendapat bahwa unsur ekstrinsik adalah unsur luar yang berpengaruh terhadap isi novel. Unsur-unsur dari luar itu meliputi latar belakang pengarang, kondisi sosial budaya, termasuk tempat novel itu dikarang."Unsur ekstrinsik merupakan hal-hal yang berada di luar struktur karya sastra, namun amat mempengaruhi karya sastra tersebut" (Tjahjono, 1988:45).

Sosiologi sastra merupakan analisis karya sastra dalam kaitannya dengankehidupan manusia dalam masyarakat yang mencakup hubungan antara seorang dengan seorang, antara perseorangan dengan kelompok, dan hubungan antara kelompok dengan kelompok. Sosiologi sastra juga dipertimbangkan objektivitas hubungan antara karya sastra dengan masyarakat, antara lain: pemahaman terhadap karya sastra dengan mempertimbangkan aspek-aspek kemasyarakatannya, pemahaman terhadap totalitas karya yang disertai dengan aspek-aspek kemasyarakatan yang terkandung di dalamnya, pemahaman terhadap karya sastra sekaligus hubungannya dengan masyarakat yang melatarbelakanginya, sosiologi sastra adalah hubungan dwiarah (dialektik) antara sastra dengan masyarakat, sosiologi sastra berusaha menemukan kualitas interdependensi antara sastra dengan masyarakat.

Sosiologi sastra juga akan mengupas nilai-nilai masyarakat, institusi sosial, dan pandangan masyarakat atau individu yang tersirat dalam karya sastra, dengan menggunakan pendekatan sosiologi sastra yang memasalahkan pembaca dan pengaruh sosial karya sastra yang dianggap mencerminkan keadaan masyarakat. Oleh karena itu, analisis sosiologi sastra berkaitan dengan analisis sosial terhadap karya sastra, baik ideologi sosial pengarang, pandangan dunia pengarang, pengaruh struktural masyarakat terhadap karya sastra atau sebaliknya, dan fungsi sosial sastra.

Hubungan antara sastra dengan masyarakat menyajikan dua pengertian yang pertama adalah karya sastra itu sendiri dengan masyarakat tertentu yang menghasilkannya dan yang kedua adalah karya sastra dengan aspek-aspek kemasyarakatan yang terkandung di dalamnya. Sosiologi sastra dalam hubungan ini berupa bagaimana suatu karya dihasilkan oleh masyarakat tertentu.

Hubungan sastra dan sosiologi sastra bahwa sastra menggambarkan atau mencerminkan dan mengekspresikan tentang kehidupan yang ada di dalam masyarakat. Menurut Wellek dan Warren (1977:111) hubungan yang bersifat deskriptif (bukan normatif) dapat diklasifikasikan sebagai berikut: 1) Sosiologi pengarang, profesi pengarang, dan institusi sastra. masalah yang berkaitan adalah tentang dasar ekonomi produksi sastra, latar belakang sosial, status pengarang, dan ideologi pengarang yang terlihat dari berbagai kegiatan pengarang di luar karya sastra. 2) Isi karya sastra, tujuan, serta hal-hal lain yang tersirat dalam karya sastra itu sendiri dan yang berkaitan dengan masalah sosial. 3) Permasalahan pembaca dan dampak sosial karya sastra. sejauh mana sastra ditentukan atau tergantung dari latar sosial, perubahan dan perkembangan sosial.

Hubungan dialektik dan karya sastra adalah karya sastra harus koheren atau cenderung koheren, karena mempunyai arti maka dari itu karya sastra berkaitan dengan usahan manusia untuk memecahkan permasalahan-permasalahan yang ada di dalam kehidupan sosial yang nyata. Untuk mendapatkan pengetahuan mengenai karya sastra semacam itu Goldman (Faruk, 2005:19) kemudian mengembangkan sebuah metode yang disebutnya sebagai metode dialektik, menurutnya: 
Metode itu merupakan metode yang khas yang berbeda dari metode positivis, metode intuitif, dan metode biografis yang psikologis. Dari segi titik awal dan titik akhirnya, metode dialektik sama dengan metode positivistik. Keduanya sama-sama bermula dan berakhir pada teks sastra. Hanya saja, kalau metode positivistik tidak mempertimbangkan persoalan koherensi struktural, metode dialektik mempertimbangkannya. Prinsip dasar dari metode dialektik yang membuatnya berhubungan dengan masalah koherensi adalah pengetahuannya mengenai fakta-fakta kemanusiaan yang akan tetap abstrak apabila tidak dibuat konkret dengan mengintegrasikannya ke dalam keseluruhan.

Hubungan sastra dan sosiologi sastra sangat erat, karena sastra menampilkan gambaran kehidupan yang mencakup hubungan antara masyarakat, masyarakat dengan orang seorang, antara manusia, dan antara peristiwa yang terjadi dalam batin sesorang. Dari karya sastra pengarang dapat mempertimbangkan aspek-aspek kemasyarakatan dan mengajarkan nilai-nilai yang berada pada masyarakat melalui tulisan-tulisan sastranya, maka dari itu karya sastra dibuat pengarang dari suatu permasalahan pengarang atau permasalahan masyarakat dan kembali pada masyarakat itu sendiri.

Salah satu permasalahan yang sering ada dalam karya sastra adalah nilai sosial. "Nilai sosial sangat penting karena manusia adalah makhluk sosial yang senantiasa berhubungan (berinteraksi) dengan manusia lain dalam suatu kelompok"( Setiadi, Elly, dan Kolip, 2011:5). Dalam hal ini diciptakanlah sebuah karya sastra sebagai media untuk menyampaikan nilai-nilai yang berhubungan dengan keadaan baik buruk suatu perilaku manusia. Dalam hal ini nilai sosial adalah nilai yang tidak bisa dilihat dengan mata, namun nilai sosial hanya bisa dijelaskan dalam bentuk perilaku masyarakat pada umumnya, berikut ini dijelaskan pemahaman tentang nilai dan nilai sosial yang dipaparkan oleh Setiadi, Elly, dan Kolip (2011:119-120) adalah:

Nilai adalah konsep-konsep umum tentang sesuatu yang dianggap baik, patut, layak, pantas yang keberadaannya dicita-citakan, diinginkan, dihayati, dan dilaksankan dalam kehidupan sehari-hari dan menjadi tujuan kehidupan bersama di dalam kelompok masyarakat tertentu, mulai dari unit kesatuan sosial terkecil hingga suku, bangsa, dan masyarakat internasional. Nilai sosial memiliki sifat abstrak, artinya nilai tidak dapat dilihat sebagai benda secara fisik yang dapat dilihat dengan mata, diraba atau difoto. Sebab nilai sosial adalah pedoman tata kelakuan bersifat pokok yang keberadaannya adalah eksis dalam keyakinan masyarakat yang hanya dapat dijabarkan dalam bentuk perilaku umum oleh masyarakat tersebut.

Nilai sosial sangat penting karena manusia adalah makhluk sosial yang senantiasa berhubungan (berinteraksi) dengan manusia lain dalam suatu kelompok. Nilai sosial hanya dapat dilihat melalui perilaku (tingkah laku seseorang atau sekelompok orang), ucapan-ucapan, dan tulisan. Nilai sosial juga sebagai petunjuk arah seperti cara berpikir, berperasaan, dan bertindak dan panduan dalam menimbang penilaian masyarakat, penentu, dan terkadang sebagai penekan para individu untuk berbuat sesuatu dan bertindak sesuai dengan nilai yang bersangkutan, sehingga sering menimbulkan perasaan bersalah bagi para anggota yang melanggarnya.

Karya sastra terdapat beberapa nilai-nilai yang bisa diambil oleh penikmat sastra itu sendiri yaitu nilai sosial, nilai moral, nilai religius, dan nilai budaya. Nilai-nilai tersebut dapat diterapkan dalam kehidupan di masyarakat. Misalnya nilai sosial, kita hidup berdampingan dengan masyarakat maka dari itu untuk menciptakan masyarakat yang rukun kita harus saling tolong menolong sesama, menghormati satu sama lain, kebersamaan, saling peduli antarsesama, menjalin hubungan kasih sayang antarsesama, dan toleransi.

Setiadi, Elly, dan Kolip (2011:83) berpendapat bahwa "toleransi merupakan tindakan yang saling memberikan peluang atau kesempatan kepada pihak lain untuk melakukan sesuatu, sehingga benih-benih pertentangan antarindividu atau antarkelompok dapat dicegah." Tolong menolong merupakan tindakan saling membantu antarsesama untuk meringankan beban satu sama lainnya. Kepedulian antarsesama merupakan perhatian dan keprihatinan antarsesama. Peduli adalah sebuah keberpihakan kita untuk melibatkan diri dalam persoalan, keadaan atau kondisi yang terjadi di sekitar kita. Saling menghormati antarsesama sangat diperlukan dalam 
kehidupan bermasyarakat. Rasa hormat kepada orang yang lebih tua ataupun kepada orang yang dihormati itu menunjukan bahwa adanya rasa menyayangi antara sesama. Kasih sayang merupakan rasa saling mengasihi satu sama lain. Kasih sayang dalam keluarga adalah cinta kasih antara suami dan istri, ayah dengan anaknya, dan ibu dengan anaknya yang dikenal sejak anak lahir dan bahkan sejak anak ada dalam kandungan. Cinta kasih yang ditunjukkan orang tua terhadap anaknya itu adalah cinta yang disertai dengan kasih sayang.

Penelitian oleh Saputra (2012) menyajikan hasilnya yakni ada enam tipe nilai sosial yaitu tolong-menolong, kasih sayang, toleransi, kepedulian, dan kebersamaan. Selain nilai sosial yang terdapat dalam novel Bukan Pasar Malam karya Pramoedya Ananta Toer juga terdapat fungsi dari nilai sosial tersebut antara lain patokan kedudukan sosial, petunjuk dalam bertindak, motivasi dalam berbuat, dan pengawasan tingkahlaku.

\section{METODE PENELITIAN}

Metode yang digunakan dalam penelitian ini adalah metode kualitatif deskriptif. Deskriptif kualitatif mengutamakan penggambaran data melalui kata-kata.Kata-kata memuat ribuan makna.setiap kata mengandung jutaan makna (Endraswara, 2013b:176). Tujuan dari penelitian kualitatif ini adalah untuk memahami kondisi suatu konteks dengan mengarahkan pada pendeskripsikan secara rinci dan mendalam mengenai potret kondisi dalam suatu konteks yang alami (natural setting), tentang apa yang sebenarnya terjadi menurut apa adanya di lapangan studi (Nugrahani, 2014:4-5).

Data dalam penulisan ini berupa paragraf yang mengandung nilai sosial dalam novel "Ayah" karya Andrea Hirata.Sumber datadalam penelitian ini adalah buku-buku, artikel dalam majalah atau surat kabar, televisi, dokumen, dan lain-lainnya.Sumber data primer dalam penelitian ini adalah dokumen yang berupa novel "Ayah" karya Andrea Hirata. Penerbit Bentang Pustaka cetakan keempat tahun 2015 dengan jumlah 412 halaman. Penentuan sumber data ini didasarkan pada pendapat Nugrahani (2014:108). Adapun data penelitian ini adalah informasi tentang nilai-nilai sosial dalam novel "Ayah" karya Andrea Hirata yang berwujud kata, frasa, kalimat, dan paragraf. Penentuan dataini sesuai dengan pendapat Subroto (1992:34).Teknik pengumpulan data yang digunakan sebagai berikut:

Dokumen utama yang menjadi bahan studi kepustakaan dalam penelitian ini adalah novel "Ayah" karya Andrea Hirata.Subroto (1992:42) berpendapat bahwa"teknik pustaka mempergunakan sumber-sumber tertulis untuk memperoleh data.'Teknik ini sangat diperlukan mengingat sumber data penelitian ini adalah novel.Untuk mendukung validitas hasil penelitian, maka penulis menggunakan beberapa referensi baik buku-buku, artikel, maupun laporan yang berhubungan dengan objek penelitian.

Pengumpulan data dengan teknik baca kritis sebagaimana dikemukaan Albert (Tarigan, 2008:89), "merupakan sejenis membaca yang dilakukan secara bijaksana, penuh tenggang hati, mendalam, evaluatif, serta analitis, dan bukan hanya mencari kesalahan." Pengumpulan data dilakukan dengan cara membaca terlebih dahulu novel "Ayah" karya Andrea Hirata. Teknik ini sangat diperlukan karena sumber data adalah sebuah novel tidak hanya membaca namun harus memahami isi di dalam novel tersebut. Teknik catat merupakan kelanjutan dari teknik membaca, dengan mencatat hal-hal penting diharapkan akan mempermudah dalam mengadakan penelitian dan membuat data tidak rusak. Menurut Subroto (1992:42), "teknik catat dapat dilakukan dengan cara mengadakan pencatatan terhadap data relevan yang sesuai dengan sasaran dan tujuan penelitian. Teknik ini sangat diperlukan karena setelah membaca objek yang akan diteliti, langkah selanjutnya adalah mencatat supaya data tersebut tidak hilang atau rusak.

Teknik pemeriksaan keabsahan data yang digunakan adalah teknik trianggulasin sumber. Menurut Sutopo (2002:79), trianggulasi sumber merupakan trianggulasi yang mengarahkan peneliti agar di dalam mengumpulkan data, wajib menggunakan beragam sumber data yang tersedia. Artinya, data yang sama atau sejenis, akan lebih mantap kebenarnnya bila digali dari beberapa sumber data yang berbeda. Trianggulasi sumber diperlukan dalam penelitian ini, karena dengan menggunakan teknik ini peneliti bisa memanfaatkan berbagai jenis sumber data yang berbeda-beda. Dengan demikian apa yang diperoleh dari sumber yang satu, bisa lebih teruji 
kebenarannya bilamana dibandingkan dengan data sejenis yang diperoleh dari sumber lain yang berbeda, baik kelompok sumber sejenis maupun sumber yang berbeda jenisnya.

Teknik analisis data yang digunakan adalah metode analisis isi (Content Analysis). "Analisis isi adalah teknik penelitian untuk membuat inferensi-inferensi yang dapat ditiru (replicable), dan sahih data dengan memperhatikan konteksnya." (Bungin, 2008:155). "Dalam penelitian kualitatif, penggunaan analisis lebih banyak ditekankan pada bagaimana simbol-simbol yang ada pada komunikasi itu terbaca dalam interaksi sosial, dan bagaimana simbol-simbol itu terbaca dan dianalisis oleh peneliti." (Bungin, 2008:158). Analisis selanjutnya digunakan dalam penelitian ini menggunakan metode hermeneutik. Ratna (Endraswara, 2013b:180) bahwa metode hermeneutika merupakan pengambilan data dilakukan secara heuristik artinya membaca karya sastra secara cermat, berulang-ulang, dibantu dengan kertas data. Cara kerja hermeneutika Ricoeur adalah langkah pertama ialah langkah simbolik atau pemahaman dari simbol ke simbol. Langkah kedua yaitu pemberian makna oleh simbol serta penggalian yang cermat atas makna. Langkah ketiga adalah langkah yang benar-benar filosofis, yaitu berpikir dengan menggunakan simbol sebagai titik tolaknya.

\section{HASIL PENELITIAN DAN PEMBAHASAN Deskripsi Pengarang}

Andrea Hirata lahir di sebuah desa yang miskin di pelosok pulau Belitung.Ia adalah anak ke-4 dari pasangan Seman Said Harun ayahnya dan NA Masturah ibunya. Desa miskin dengan kehidupan di dalamnya serba pas-pasan secara langsung mempengaruhi kepribadian Andrea sejak kecil.Kepribadian Andrea terbentuk dari lingkungan yang memprihatinkan, sedih, penuh dengan rintangan hidup yang berat.Andrea Hirata adalah sorang penulis yang namanya melambung pada tahun 2008 dengan karyanya yang pertama ialah "Laskar Pelangi"."Laskar Pelangi" ditulis Andrea pada tahun 2005.

Lewat keberhasilan penjualan novel pertama dan antusias pembaca yang banyak, pada tahun 2008 dua orang sutradara terkenal di dunia perfilman Indonesia Riri Riza dan Mira Lesmana memproduksi sebuah film yang berjudul "Laskar Pelangi" yang diadaptasi dari novel "Lakar Pelangi" karya Andrea Hirata. Tidak jauh berbeda dengan antusias penjualan novel film "Laskar Pelangi" pun sama menjadi salah satu film yang banyak ditonton di Indonesia dengan capaian sekitar 4.6 juta penonton di seluruh Indonesia. Lewat kesuksesannya dalam menulis novel dari tahun 2005 diawali dengan best seller "Laskar Pelangi". Beberapa karya novel yang sudah dibuat oleh Andrea Hirata anatar lain: Laskar Pelangi (2005), Sang Pemimpi (2006), Edensor (2007), Maryamah Karpov, Padang Bulan dan Cinta di Dalam Gelas (2010), Sebelas Patriot (2011), Laskar Pelangi Song Book (2012), Ayah (2015).

\section{Kepedulian Antarsesama}

Nilai sosial yang digambarkan pengarang dalam novel "Ayah" tercermin kepedulian antarsesama. Hal ini tergambarkan ketika para sahabat memberi perhatian kepada tokoh Sabari untuk tidak memikiran seorang wanita terus-menerus wanita itu bernama Lena, dia adalah wanita yang sangat dicintai oleh tokoh Sabari namun Lena tidak suka dengan tokoh Sabari ini. Suatu saat sapautangan Lena jatuh di lapangan upacara, kemudian tokoh Sabari ini mengambilnya lalu menyerahkannya kepada Lena, justru marah-marahlah yang di dapat oleh tokoh Sabari. Tidak ada kata menyerah di hidup tokoh Sabari ini dia kemudian memberi buku tulis untuk Lena, tetapi Lena menolak buku itu. Tokoh Sabari pun merasa gelisah, kecewa, kemudian menderita. Semua orang yang melihatnya tak habis pikir seorang lelaki hanya terpaku satu perempuan, tidak bisa dialihkan ke perempuan lain, seolah dunia ini hanya ada satu wanita yang bernama Lena. Termasuk para sahabat dari tokoh Sabari yang tak habis pikir melihat sahabatnya yang tengah kasmaran dengan wanita dan yang ada dipikirannya hanyalah wanita itu saja. Seperti terlihat dalam kutipan berikut ini.

"Kawan dekat Sabarai, yakni Maulana Hasan Magribi-lahir saat azan Maghrib-bisa dipanggil Ukun dan Mustamat Kalimat, bisa dipanggil Tamat, berkali-kali mengingatkan Sabari bahwa dia bisa berakhir di Panti Rehabilitasi Gangguan Jiwa Amanah di bahwah pimpinan Dra. Ida Nuraini, apabila kepalanya yang ditumbuhi 
rambut keriting bergumpal-gumpal itu hanya dipenuhi bayangan Lena. Sabari bergidik. Dia pun sering mengingatkan dirinya sendiri akan hal itu.” (Ayah: 3).

\section{Hubungan Kasih Sayang Antarsesama}

Nilai sosial yang digambarkan pengarang dalam novel "Ayah" tercermin dari hubungan kasih sayang antarsesama. Hubungan kasih sayang antara ayah dan anak tercermin ketika sang ayah merangkap perannya menjadi seorang ibu yang selalu siaga ketika sang anak membutuhkannya. Seperti tergambar di bawah ini.

"Sabari adalah ayah sekaligus ibu bagi Zorro, full time. Dia menyuapi Zorro dan meminuminya susu. Dia terjaga sepanjang malam jika anak itu sakit.Dia telah mengalami saat-saat panik waktu si kecil demam.Dia membawanya ke puskesmas seperti layaknya dilakukan seorang ibu.Dia tahu perkara gizi balita, vaksin, dan obat anak-anak.Bahkan, dia sering memberi tahu ibu-ibu lainnya soal itu. Pesan Sabari, bayi jangan terlalu sering diminumi air tajin, kalau terlalu sering, nanti jika besar tak bisa matematika macam Toharun, Ukun, dan Tamat."(Ayah: 184).

Kutipan di atas menggambarkan kasih sayang ayah yang merangkap menjadi ibu kepada anaknya. Tokoh Sabari ini yang telah menjadi ayah merangkap perannya, maksudnya selain menjadi ayah tokoh Sabari ini juga berperan menjadi ibu setelah ditinggal sang istri pergi entah kemana. Tokoh Sabari ini selalu menyuapi dan memberi minum susu yang biasanya pekerjaan itu dilakukan seorang ibu. Kemudian sang ayah ini sudah mengalami saat-saat yang membuatnya merasa panik ketika itu sang anak demam. Segera sang ayah membawanya ke puskesmas layaknya sorang ibu yang selalu tanggap akan keadaan anaknya. Tokoh Sabari ini juga tau tentang gizi balita, vaksin, obat anak-anak, bahkan dia sering mengingatkan para ibu-ibu untuk tidak memberi minuman yang berasal dari air beras biasanya disebut air tajin karena kelak waktu sang anak besar kurang pintar soal matematika. Kasih sayang seperti ini mungkin jarang kita lihat untuk dewasa ini kasih sayang sang ayah yang selalu perhatian kepada anaknya dan di sisi lain dia juga berperan merangkap selain menjadi ayah dia juga berperan menjadi ibu yang selalu sigap ketika sang anak terjadi apa-apa.

\section{Kebersamaan}

Nilai sosial yang digambarkan pengarang dalam novel "Ayah" tercermin dari kebersamaan. Hal ini tergambarkan ketika para warga mendengar berita yang isinya mengenai orang yang diidolakan satu kampung dan mereka berkerumunan di depan televisi, ketika sang idola itu muncul mereka segera berdiri dan mendekati televisi karena ingin melihat sang idola dari jarak dekat walaupun itu di dalam televisi, seperti terlihat dalam kutipan berikut ini.

"Lady Diana adalah kembang dunia yang selalu membesarkan hati orang miskin, kata mereka. Jika ada berita Ledy Diana mengunjungi kampung miskin nun di belahan dunia antah-berantah, mereka mendekatkan telinga ke radio atau berkerumun di depan televisi umum, Sanyo hitam putih, empat belas inci, di pekarangan balai kampung. Lady Diana muncul di layar, mereka berdiri dan mendekati TV karena mau melihat Lady Diana

\section{Menghormati} dari dekat." (Ayah: 7).

Nilai sosial yang digambarkan pengarang dalam novel "Ayah" tercermin saling menghormati. Hal ini tergambarkan ketika tokoh Amiru minata izin untuk mengaja adik-adiknya jalan-jalan dan sebelum berangat Amiru mencium tangan ibunya, seperti terlihat dalam kutipan berikut ini.

"Pada hari perlombaan, Amiru minta izin kepada ayah dan ibunya untuk mengajak adik-adiknya jalan-jalanke ibu kota kabupaten.Sebelum berangkat, dia mencium tangan ibunya lama sekali." (Ayah: 90).

\section{Tolong-Menolong Antarsesama}


Nilai sosial yang digambarkan pengarang dalam novel "Ayah" tercermin tolongmenolong antarsesama. Hal ini tergambarkan ketika tokoh Amirza meminta bantuan Amiru untuk mengambil baterai yang sedang dijemur di atap rumah. Seperti terlihat dalam kutipan berikut ini.

"Antena selesai ditautkan.Amirza meminta Amiru mengambil batu baterai yang sedang dijemur di ataprumah.Segera Amiru melaksanakan perintah itu." (Ayah: 24).

Kutipan di atas menggambarkan saling tolong-menolong antara orang tua dan anaknya. Tolong-menolong ini tercermin ketika sang ayah Amirza meminta bantuan kepada anaknya Amiru untu mengambil batu baterai yang sedang dijembur di atap rumah, dan segera Amiru melaksanakan perintah dari sang ayah. Tolong-menolong ini merupakan sikap saling membantu untuk meringankan beban satu sama lainnya, pada dasarnya manusia adalah makhluk sosial yang tidak bisa hidup sendiri tanpa bantuan orang lain. Oleh karenanya kehidupan di dalam masyarakat memerlukan adanya kerjasama dan saling tolong-menolong.

\section{Toleransi}

Nilai sosial yang digambarkan pengarang dalam novel "Ayah" tercermin nilai toleransi. Hal ini tergambarkan ketika tokoh Amiru diam saja dan tidak mau mengecilkan hati sang ayahnya yang sedang dilandaawan-awan ilmiah. Seperti terlihat dalam kutipan berikut ini.

"Akan tetapi, Amiru diam saja.Tak mau dia mengecilkan hati ayahnya yang sedang dilanda awan-awan ilmiah.Lebih-lebih karena dia tahu makna radio itu bagi ayahnya.Serius dia menonton aksi ayahnya.Melihat anaknya memandangnya dengan penuh kagum, Amirza semakin gesit.” (Ayah: 24).

Kutipan di atas menggambarkan nilai toleransi antara anak dengan ayah yang menimbulkan rasa yang damai. Toleransi itu terjadi pada tokoh Amiru yang diam saja dan tidak mau mengecilkan hati ayahnya karena sang ayah sedang dilanda awan-awan ilmiah untuk memperbaiki antena radio supaya tidak buruk suaranya.

\section{SIMPULAN}

Berdasarkan hasil penelitian yang telah dijabarkan dapat disimpulkan bahwa Nilai-nilai yang ada dalam novel "Ayah" karya Andrea Hirata adalah kepedulian antarsesama meliputi; kepedulian antarsahabat, kepedulian antarsesama, dan kepedulian antara guru dengan muridnya. Hubungan kasih sayang antarsesama meliputi; hubungan kasih sayang antara kakak dengan adiknya, hubungan kasih sayang antara anak dengan ayahnya, hubungan kasih sayang anak dengan kedua orang tuanya, hubungan kasih sayang antara suami dan istri, hubungan kasih sayang antara ayah dengan anaknya, dan hubungan anak dengan ibunya. Kebersamaan meliputi; kebersamaan antarsesama, kebersamaan antarsahabat, dan kebersamaan ayah dan anak. Menghormati meliputi; meghormati dan sopan santun kepada orang tua dan menghormati dalam hal kompetisi atau pertandingan. Tolong-menolong meliputi; tolong-menolong antara orang tua dengan anaknya, tolong-menolong antarsesama, dan tolong-menolong antarteman. Toleransi meliputi; toleransi antara anak dan ayah dan toleransi antarsesama.

\section{DAFTAR PUSTAKA}

Bungin, Burhan. 2008. Penelitian Kualitatif. Jakarta: Kencana.

Endraswara, Suwardi. 2013a. Sosiologi Sastra. Yogyakarta: Ombak. 2013b. Metodologi Kritik Sastra. Yogjakarta: Ombak.

Faruk. 2005. Pengantar Sosiologi Sastra dari Strukturalisme Genetik sampai Post-Modernisme. Yogyakarta: Pustaka Pelajar. 2012. Pengantar Sosiologi Sastra. Yogyakarta: Pustaka Pelajar.

Hirata, Andrea. 2015. Ayah. Yogyakarta: Bentang.

Kosasih. 2012. Dasar-Dasar Keterampilan Bersastra. Bandung: Yrama Widya. Nugrahani, Farida. 2014. Metode Penelitian Kualitatif. Surakarta: CakraBook Solo. Nurgiyantoro, Burhan. 2007. Teori Pengkajian Fiksi. Yogyakarta: Gadjah Mada University Perss. 
Saputra, Wahyu. 2012. "Nilai-nilai Sosial dalam Novel Bukan Pasar Malam Karya Pramoedya Ananta Toer". Jurnal Pendidikan Bahasa dan Sastra Indonesia. Vol. 1, No. 1, September 2012; Seri E 339-425. hal 409-417.

Setiadi, Elly M dan Usman Kolip. 2011. Pengantar Sosiologi Pemahaman Fakta dan Gejala Permasalahan Sosial: Teori, Aplikasi, dan Pemecahannya. Jakarta: Kencana.

Subroto, Edi. 1992. Pengantar Metoda Penelitian Linguistik Struktural. Surakarta: Sebelas Maret University Press.

Sutopo. 2002. Metodologi Penelitian Kualitatif. Surakarta: Sebelas Maret Univesity Press.

Tarigan, Henry Guntur. 2008. Membaca Sebagai Suatu Keterampilan Berbahasa. Bandung: Angkasa.

Tjahjono, Liberatus Tengsoe. 1988. Sastra Indonesia Pengantar Teori dan Apresiasi. FloresNTT: Nusa Indah.

Wellek, Rene dan Austin Warren. 1977. Theory of Literature. Diterjemhakan oleh Melani Budianta dengan judul Teori Kesusastraan. Jakarta: PT Gramedia. 